\title{
LETTERS
}

\section{Investing appropriately to alleviate child poverty in Canada}

We applaud Dr. Trevor Hancock's timely article, "Reducing the cost of inequality," and wholeheartedly agree that there are good ethical reasons for reducing inequality in Canada. Further, we certainly agree with Dr. Hancock that the cost of health inequality is substantial, both in years of life lost and costs to the Canadian economy. ${ }^{1}$ It is also a substantial challenge to the Canadian health care system. Therefore, there are valid reasons to invest appropriately to alleviate overall poverty and, specifically, child poverty in Canada. Reducing the number of Canadians living in poverty, including our vulnerable children, should be a social policy priority. Although the theme of child poverty in Canada has grabbed much public, media and political attention, according to recent statistics, 4.8 million Canadians lived in a low-income household in 2015, of whom 1.2 million (nearly one in four) were children. ${ }^{2}$

Recently, the World Health Organization concluded, "Social injustice is killing people on a grand scale." 3 There is a rationale for taking action to improve the lives of those living in poverty. Social determinants and health inequalities pose a substantial challenge to health care systems around the world.

The Organisation for Economic Cooperation and Development stated, "Failure to tackle the poverty and exclusion facing millions of families and their children is not only socially reprehensible, but it will also weigh heavily on countries' capacity to sustain economic growth in years to come." 4

Poverty has been highlighted as the most important social determinant of child health in high-income countries. ${ }^{5-7} \mathrm{~A}$ recent United Nations Children's Fund Report Card examined a children's wellbeing index, looking at the average of 26 indicators across 5 dimensions: material well-being, health and safety, education, behaviours and risks, and housing and environment. ${ }^{6}$ Canada's overall rank was 17 th of 29 wealthy developed nations. ${ }^{6}$ It ranked 15 th in material wellbeing, 27th in health and safety, 14th in education, 16th in behaviours and risks, and 11th in housing and environment. League tables for each of these dimensions, and for each indicator within the dimension, measure and compare progress for children across these countries.

We also need to understand that children are often not in a position to speak out for themselves, and every child is therefore entitled to special protection under the United Nations Convention on the Rights of the Child. The argument is not just about evidence underlying the interventions, or their cost-effectiveness; it is that making genuine effort to reduce child poverty is morally and legally the right thing to do. ${ }^{5,7}$

Article 24 of the United Nations Convention on the Rights of the Child says: "States Parties recognize the right of the child to the enjoyment of the highest attainable standard of health and to facilities for the treatment of illness and rehabilitation of health. States Parties shall strive to ensure that no child is deprived of his or her right of access to such health care services." 8,9 Moreover, poverty affects child growth, development and well-being, as reflected by birth weight (comparatively poorer children are at greater risk of low birth weight) and language acquisition (less likely to be reading by second grade). Poor children are more likely to drop out of high school and less likely to go on to secondary education. They are also vulnerable to many chronic illnesses and accidental injury..$^{10,11}$ Poverty also leads to problems with diet and mental health. ${ }^{12}$

Overall, a child's health serves as a foundation for health across the lifespan. ${ }^{13}$ There is increasing consensus that early child care and education programs are crucial and comprise the most costeffective investment in children's early years of growth and development. ${ }^{11}$

Our children need us to speak for them to ensure their best possible future. The public health community, including doctors, can have a strong voice in advocating for the implementation of proven poverty reduction strategies to make our vulnerable communities healthier, safer, stronger and more prosperous for everyone. ${ }^{14}$

The Canadian Paediatric Society has expressed substantial concern about child poverty and social inequality and the negative effect this can have on children's overall health and well-being. ${ }^{15}$ Further, the society has explored actions that can be taken to prevent and mitigate this substantial social problem that could deeply affect Canada's future. ${ }^{15}$ It provides a range of recommendations for policymakers, as well as ways for doctors to act as advocates for patients who face the harmful effects of child poverty. ${ }^{15}$ The society suggests that all stakeholders, and governments at all levels, work together toward eliminating child poverty, in a way that incorporates the following evidencebased solutions: income support measures, education and job training, and quality child care programs. It also encourages provinces and territories to pass legislation to reduce poverty levels and develop antipoverty strategies. ${ }^{15}$

The American Academy of Pediatrics policy on health equity emphasizes that clinic visits are opportunities to screen and appropriately address the social, economic, educational, environmental and person-capital needs of children and families. In addition, the American Academy of Pediatrics advises pediatricians to find ways to link families with resources and programs that can help them help their children to thrive. ${ }^{11,16,17}$ It also encourages pediatricians to engage on affordable, quality health care; child care; education; housing; nutritious food; family supports; and guarantees of a living wage. ${ }^{11,16,17}$

With sensible and increased investment, government and stakeholders can play a stronger role in tackling child poverty. Government should also ensure that it is in full partnership with stakeholders in tackling child poverty. It is important that we support all our children to live to their full potential. Poverty is bad for our children and their lifelong health and well-being. We need to address child poverty and social inequality and support social and public policies to promote 
child well-being, and support all our children to live up to their full potential by providing necessary knowledge, appropriate skills, equal opportunities, and a safe and nurturing environment in which to grow. This is part and parcel of fulfilling Canada's capacity for sustainable social economic growth in the future.

\section{Ediriweera Desapriya PhD}

Research associate, Department of

Emergency Medicine, Faculty of Medicine, University of British Columbia, Vancouver, BC

\section{Parisa Khoshpouri MD}

Research assistant, Department of Emergency Medicine, Faculty of Medicine, University of British Columbia, Vancouver, $\mathrm{BC}$

Cite as: CMAJ 2018 July 3;190:E805-6. doi: $10.1503 / \mathrm{cmaj} .69470$

\section{References}

1. Hancock T. Reducing the cost of inequality. CMAJ 2018;190:E92.

2. Census in brief: children living in low-income households. Ottawa: Statistics Canada; 2017 Sept.
13 (released). Available: www12.statcan.gc.ca/ census-recensement/2016/as-sa/98-200-x /2016012/98-200-x2016012-eng.cfm (accessed 2018 Mar. 3).

3. CSDH. Closing the gap in a generation: health equity through action on the social determinants of health. Final Report of the Commission on Social Determinants of Health. Geneva: World Health Organization; 2008. Available: www.who.int/ social_determinants/final_report/csdh_finalreport _2008.pdf (accessed 2018 Mar. 3).

4. Combating poverty and social exclusion through work, policy brief. Paris: Organisation for Economic Co-operation and Development Publishing; 2005.

5. UNICEF Report Card 10: Poverty ... The one line we want our kids to cross. Toronto: UNICEF Canada; 2016. Available: www.unicef.ca/en/our-work/article /unicef-report-card-10 (accessed 2018 Mar. 1).

6. Child well-being in rich countries: a comparative overview. Innocenti Report Card 11. Florence (Italy): UNICEF Office of Research; 2013. Available: www.unicef-irc.org/publications/pdf/rc11_eng.pdf (accessed 2018 Mar. 3).

7. Sidebotham P, Fraser J, Covington $\mathrm{T}$, et al. Understanding why children die in high-income countries. Lancet 2014;384:915-27.

8. General comment no. 5: General measures of implementation for the Convention on the Rights of the Child 03/10/2003. CRC/GC/2003/5. New York: United Nations Committee on the Rights of the Child; 2003. Available: www.unicef-irc.org/portfolios/general_ comments/GC5_en.doc.html (accessed 2018 Mar. 1).

9. Lansdown G. Every child's right to be heard: a resource guide on the UN committee on rights of the child general comment No 12. London (UK):
Save the Children UK; 2011. Available: www.unicef. org/french/adolescence/files/Every_Childs_Right_to _be_Heard.pdf (accessed 2018 Mar. 4).

10. Pascoe JM, Wood DL, Duffee JH, et al.; Committee on Psychosocial Aspects of Child and Family Health. Council on Community Pediatrics. Mediators and adverse effects of child poverty in the United States. Pediatrics 2016;137:e20160340.

11. Klass P. Saving Tiny Tim - Pediatrics and childhood poverty in the United States. N Engl J Med 2016;374: 2201-5.

12. Health at a price - Reducing the impact of poverty: a briefing from the board of science, June 2017. London (UK): British medical Association (BMA); 2017.

13. Irwin KG, Siddiqui A, Hertzman C. Early child development: a powerful equalizer. Final report. Geneva: World Health Organization; 2007.

14. Pickett KE, Wilkinson RG. The ethical and policy implications of research on income inequality and child well-being. Pediatrics 2015;135(Suppl 2): S39-47.

15. Are we doing enough? A status report on Canadian policy and child and youth health. Ottawa: Canadian Pediatric Society; 2012. Available: www.cps.ca/ uploads/advocacy/StatusReport2012.pdf (accessed 2018 Mar. 7).

16. Cheng TL, Emmanuel MA, Levy DJ, et al. Child health disparities: What can a clinician do? Pediatrics 2015;136:961-8.

17. Council on Community Pediatrics and Committee on Native American Child Health. Policy statement Health equity and children's rights. Pediatrics 2010;125:838-49.

Competing interests: None declared. 